doi:10.1093/jdh/epv054 Journal of Design History Vol. 29 No. 1
(C) The Author [2016]. Published by Oxford University Press on behalf of The Design History Society. All rights reserved.

\section{Design Dispersed: Design History, Design Practice and Anthropology}

\section{Pauline Garvey and Adam Drazin}

Keywords: anthropology—applied practice—design history—ethnography

This special issue is part of a rising tide of literature dedicated to design in the discipline of anthropology. In this publication, we respond supportively to Lucy Suchman's call that '[. . .] we need less a reinvented anthropology as (or for) design than a critical anthropology of design'. ${ }^{1}$ Arriving at this academic moment entails at least two scholarly trajectories that have been hitherto distinct, concerning how anthropology has engaged with design history on the one hand, and with design practice on the other.

The first trajectory concerns convergences between design history and anthropology since the 1980s, resulting in several seminal works. For much of the mid-twentieth century, design history focused on the development of designed forms, with especial reference to aesthetics, and the lives of identified design practitioners. Breaking with this tradition came scholars who were part of an innovative vanguard, such as Penny Sparke, Adrian Forty and Judy Attfield, each of whom shifted the frame of focus to encompass a social history mediated by design forms and practices. When The Journal of Design History $(J D H)$ first appeared in 1988, it was a part of a reinvigorated design history, which was explicitly connecting with anthropology and other social sciences.

The year 1986 stands out for landmark publications that mark this new departure. In this year Sparke published the first edition of An Introduction to Design and Culture in the Twentieth Century, in which she establishes the validity of considering design within a socio-political lens. Rather than focusing on the role of designed things only as the products of skill, judgement and work, she locates them in a wider social nexus, in which designed things are situated within socio-economic, political and cultural actions and aspirations. In the same year, Forty's Objects of Desire presented insightful work on the contexts of production and consumption, situating designed things within office and domestic contexts and interrogating their use in creating new or foreclosing on previous practices. In these works, meanings and actions are not initiated solely by designers but are emergent through cultural practices. Lastly, a very direct engagement with anthropology is evident in the work of Judy Attfield. Her 1989 collaborative publication with Pat Kirkham, The View from the Interior, drew attention to the role of ethnographic methods, by fragmenting perspectives on design history. The people with whom she worked 'lived' design, and hence, partly because of design and everyday modernism, they 'lived in' history. These nuanced, sometimes admirably partial viewpoints on culture, design and history contributed to the justification of the vernacular eye in design history, which was explored in greater detail in Wild Things. ${ }^{2}$ This work also enabled the appreciation of a much more contested political terrain for design.

This innovative shift in research objectives in the discipline of design history levered open new loci of scholarship, and came about when similar innovations were occurring elsewhere in the social sciences and humanities. For example, during the 1980 s material culture studies emerged as an interdisciplinary field, particularly within anthropology, archaeology and museum studies. ${ }^{3}$ The 1990 s witnessed further avenues for productive interdisciplinary collaboration, specifically in the 'agentive turn' in anthropology 
in which agency was attributed to things and subject-object hybrids were identified. ${ }^{4}$ Scholars such as Alfred Gell stand at the forefront of this intellectual movement, for instance in his identification of the 'nexus of intentionalities' that binds an invention, its inventor and subject, while in science and technology studies Bruno Latour, amongst others, identified the insecure boundaries between non-human technological projects and their human counterparts. ${ }^{5}$ Such perspectives have been productively employed in tracing 'objects-in-action' that bind persons and things, both in design history and in studies of emergent designs. ${ }^{6}$ For example, replacing 'designed things' as finished products is Suchman's anthropologically-informed argument that objects are 'affiliative'; they adumbrate alliances or divisions between people. ${ }^{7}$ Studies in material culture are then well placed, as a bridge between anthropology and design history, to facilitate interdisciplinary scholarship through an exploration of entanglements between people and things. Design may conventionally refer to the work of practitioners (ranging from artistic through technical to graphic and other ends of the design spectrum) and the works produced; but here we adopt an expansive definition that disturbs disciplinary fields and incorporates the material and ideational undertow of political, institutional, corporate and creative human and non-human practice. Following Suchman, the best way to understand design is to shift the frame of focus and explore what lies beyond the designer's frame. This requires '[. . .] ethnographic projects that articulate the cultural imaginaries and micropolitics that delineate design's promises and practices'. ${ }^{8}$ Her argument potentially brings together the two separate trajectories of engagement between design and anthropology, that of writing a social history through design, and that of design anthropology.

This leads us to the second intellectual trajectory under focus here, which concerns collaborations between applied anthropology and specific areas of design practice. Many publications have outlined this history, which emerged through human-centred design, and the use of ethnographic methods and anthropological thinking in informational and IT systems design. ${ }^{9}$ In recent decades a large body of scholarship has placed these collaborations under reflexive scrutiny, each considering the rich possibilities of both disciplines. ${ }^{10}$ Gunn and Donovan write about the differences between anthropology 'of, with and for' design, signalling that design anthropology can favour the aims of design practice, or anthropology, but that these aims are not necessarily the same. ${ }^{11}$ In the formation of a 'design anthropology', previous problem-oriented approaches have given way to an engagement with the object of design and its generative capacity in creating new social practices and performances. ${ }^{12}$ Hence, rather than a concern with 'users', we now find anthropologists focusing on the forms of cultural production elicited by new technologies, and on the environments in which these devices are situated. ${ }^{13}$ Similarly the unstable boundaries between design and use have been interrogated. Scholars now acknowledge that design continues through transmission and use, that individuals appropriate designs beyond the expectations of designers, and indeed that designed objects are no more static than their users, but alter through material engagements with actual environments. ${ }^{14}$ While the two trajectories we have outlined have hitherto been codified as occurring at opposite ends of the wide spectrum of design studies - either as marking past milestones or as a vanguard for the future-at the current moment they are converging in interesting ways. Clarke notes a 'seismic shift' in the terms of engagement between practitioners and users and their material environments. ${ }^{15}$ Since people appropriate designs beyond what designers intend or anticipate, so the design process must necessarily remain open to how people reconfigure their worlds in everyday life. But beyond that, Clarke also notes the vertiginous diversity of 'processes, practices and materialities involved in the making of stuff', and the multiplicity of actions that now come under the heading 'design'. ${ }^{16}$ In a context in 
which designers may be found conducting historically-situated social research as much as creating form, and in which consumers are called upon to co-author their favourite brands and personalize products, she questions if the term 'design' is sufficient to capture this ever expanding set of practices. This special issue builds on these problematics, and pushes at the boundaries of the term 'design' rather than foreclosing it. Bearing this in mind our approach to design is less focussed on it as an immutable or applied activity and more as a dispersed one.

The anthropologists who have contributed to this Special Issue of The Journal of Design History are united in their belief that critical attention to design-beyond the designer's frame-is one of the most interesting frontiers of the anthropological discipline. This means exploring design as a nexus for cultural phenomena, and the use of designinspired methodologies to think about culture. At the present moment, across the world design is becoming much more prevalent in social life. Indeed, Latour suggests that it has been substituted for earlier ideas of modernization or revolution. ${ }^{17}$ Popular cultures consume notions of design. Professional cultures deploy design in political policy and economic action. Material culture is appreciated as 'design'. Design methods are looked to in order to culturally renovate, redeem and lend value to distinct traditions and heritages. Design knowledges and skills infuse the articulation of personal identities, so that people often see themselves as engaging with their worlds through design-informed paradigms.

\section{Design history and an 'anthropology of the contemporary'}

If, then, the dialogue between anthropology and design history is a mutually-beneficial one, in which both disciplines gain a degree of reflexivity and a sense of 'location' in space and time, what are the particular concerns for anthropologists turning to design? Some direct their attention to exploring what social forms are generated or facilitated through the design designation, in effect the question of what design may comprise in cultural terms. In this issue, these include corporate or governmental machinations, the politics of design as vernacular action, and unexpected actors at work in design processes. Cultural conceptions of history and temporality are a recurrent interest, and feature prominently here.

Rabinow et al. contend that working with design offers the potential for anthropologists to reinvent their discipline as an 'anthropology of the contemporary'. ${ }^{18}$ However, instead of a 'call to the vanguard', Suchman suggests that design is best positioned as a problematic object for an anthropology of the contemporary, which involves a realization of continuity and change that is not hinged on ideas of linear or uniform progression, and where designers are not the sole authors of emergent materialities and technologies. This requires adopting a critical anthropology of design, and practices such as revealing the contingencies of design knowledge among diverse audiences. Ton Otto's article explores some of the problematics that Suchman identifies. In placing design activity in a cross-cultural perspective, he throws light on how multiple conceptions of history (historicity) come to the fore in design activities. He first establishes a broad and inclusive definition of design, such as an exploration of skilled activities that are 'cultural performances that all involve an element of intentional change'. Because of this sense of intentional change, historicity is placed at the heart of what Otto considers design is. He argues that design actions involve not only a vision or imagination of the future, but a corresponding and fitting imagination of the past (or history), and encompass the processes by which we relate to each. Otto considers three key case studies: first, one from Baluan island; secondly, one in a Yolngu community in Australia; 
and thirdly, one in Denmark. Each of these projects is framed as making or remaking a sense of the community's future, and specifies a sense of progression. In the Baluan example, Otto points out how people who used to talk about kastam (broadly, 'tradition') are now talking more about kalsa (broadly, 'culture'). This move over some years towards a local idea of culture increasingly displaces ideas of tradition and reflects a shifting sense of historicity. Increasingly, the community sees itself as future-oriented, and as kalsa its cultural performances (and designs) are subject to looser notions of ownership, being apportioned to regions or the island as a whole. Seen in the light of this background, projects aimed at 'digital natives' in Denmark highlight in sharp relief the cultural and social dimensions of design work. Rather than being simply about how to design the digital, or how people may use digital design, the project is seen as involving a progression of cultural formations, in which a temporal conception of identity and community in Denmark is being negotiated and materialized.

Otto's theorization of how design relates to its historicity in different locations is an example of the productive exchange between design and anthropology. But we are mindful also of the complex relationships between anthropological scholarship and collaborations with industry and applied practices. Many of the familiar technologies that surround us have been made with the critical input of anthropologists: 'The things and lives which digital anthropologists work on are in small part products of anthropology as well as study objects, but you will not always find this acknowledged in books and articles.' ${ }^{19}$ Adam Drazin calls for an enhanced self-consciousness among anthropologists of their place in the shaping of cultural industry. In reviewing the trajectory between anthropology, digital media and design, he highlights that the history of applied design in anthropology or design-inspired methodologies is not generally represented in the mainstream anthropological canon. In contrast, design history departments often exist in design schools alongside various fields of design practice. This creates conditions for a productive and dialogic relationship between design history and varied design practices. ${ }^{20}$ Anthropological inputs into contemporary technologies, for example, should induce us to consider the historicity of applied anthropological practice and scholarship more broadly. Related to this is Alison Clarke's article in this volume, in which she highlights how development politics and anthropological paradigms were integral to the development of industrial design since the 1970s. Clarke uncovers how traditional design history approaches focussed on icons of western capitalist economies to the neglect of the embeddedness of industrial design aspirations within Cold War development politics. Taking the example of the Ahmedabad Declaration, often pitched as a defining moment in recognizing the potential of industrial design in 'developing' economies, she illustrates how it acted as harbinger of diplomatic relations between India and western economies and charts the rise of a specific form of development design, informed by quasi-anthropological concepts. In her analysis Clarke uncovers a mix of unrealized political aspirations for design as a catalyst of change, within the context of India-Western relations. The potential of design was seen to harbour a new horizon of social and industrial change that celebrated both the vernacular and the new. In challenging the commonly-understood narrative of the moment of the declaration, Clarke destabilizes a viewpoint that hinges on the origin of social change through innovative design work, and relocates design as a political and social relation.

Gabriela Nicolescu's article also merges issues of temporality and politics in her examination of ethnographic displays in socialist Romania. Questioning why socialist museums and their mechanics of display were purposively transient in comparison to their Western European counterparts, she explores the effect of the display mechanics on embedding socialist ideals of work and progress in material form. Ethnographic 
displays - meaning here vernacular objects from the Romanian rural past, but often stripped of a social commentary-paradoxically levered distance between the peasants and their own history. While the exhibits worked to distance rural communities from the idealization of the peasantry, the trope of design was pivotal in the promotion of scientific museum practices and concomitant expressions of citizenship

The unstable territory between vernacular skills and design practices is under scrutiny in Stephanie Bunn's article, which challenges conventional dualities between the designations of 'craft' and 'design'. Bunn takes an example of Scottish basketry as passed down through families but also undertaken by specialists. Basketry represented a male, specialist craft, often undertaken to earn some extra money. Commonly termed a vernacular craft, the form of each new basket was viewed as an emergent skill, something that involved no intentional design, but developed through a less self-conscious process called 'tradition'. Bunn argues, however, that the dispersed and embodied engagements represented by basketry provide a medium to challenge polarities between design and craft, tradition and innovation, and industrial versus vernacular ways of life. Basketry did not lend itself to mechanization but baskets were consumer objects nevertheless, and their makers exhibited innovation and prescient planning in responding to new social needs in both rural and urban settings. Indeed, some of these represented cutting-edge social forms 'from surgical dressings to hot air balloons', until finally replaced in the mid-twentieth century by sacks, shopping trolleys and plastic bags. Challenging commonly-understood accounts of the historically-emergent relationship between design and crafts, that of intentional design versus emergent skill, this is in some sense a culturally-alternative design history. As an anthropologist deploying a design history approach, she relocates design through challenging its boundaries.

The final article in this issue questions how design intersects with notions of humanity and intentionality. Eleanor Morgan adopts a historical and ethnographic approach to address questions pertinent to both ecological design and anthropology. Morgan asks how we might understand spider silk, either in natural or artificial forms, as the work of specific species of spiders or the result of human creativity. Focusing on two spider silk objects - a cape exhibited in the Victoria and Albert Museum in 2012 and a hood made in the early twentieth century on the island of Malakula in Vanuatu-she pitches the properties of silk within shifting geohistorical contexts but also within the ecology of the spiders themselves. After all, she observes, the design process is not only reliant on social contexts, but also on natural ones. Design, she illustrates, is dispersed in 'material, mythical, historical and bodily associations that are entangled in the making processes of specific spiders'. The significance of the objects is integrally linked as much to the materials used, the luminous glow of the silk or the sticky texture of the webs, as to ideas of life and death in Vanuatu or to suspicions by western collectors surrounding viscous materials. Design in its most expansive definition requires attention to non-human actors as well as to human ones, and to the unfinished nature of the designed object.

Anthropology comprises first and foremost the study of humanity, and the dimensions of what makes humans the same or different. Some definitions of design might suggest that it is not only a product of human action, but a characteristic of humanity and human intentionality per se. One can then ask whether non-human species can design, such as spiders (Morgan in this volume). In a similar vein, anthropology examines cross-cultural trajectories of design, unpacking whether one can have a global design history, or multiple histories. ${ }^{21}$ Design can be particularly provoking, because it evokes a hierarchical dimension to culture, in so-called 'high' and 'vernacular' forms of design and in the designation of craft (Bunn in this volume). As anthropology acts as 
a mode of engagement with design's 'users', and attempts to reconfigure how these engagements are conceptualized, the history of such engagements between professional and popular spheres becomes a high priority (Clarke and Nicolescu in this volume). The current intellectual moment is highly significant for engagements between design and anthropology, perhaps even as significant as the moment of intellectual foment in the late 1980s when JDH first appeared. Many thinkers, alongside Suchman, have attempted to synthesize what characterizes this moment, but interdisciplinarity is one such feature. Mutual interdisciplinary engagement is not a simple task however. It concerns questions of whether we must inevitably co-opt methods, work practices and academic purposes, and on what grounds it is academically productive to do so. This edition of $J D H$ itself comprises one encounter. In inviting a design history audience into anthropological accounts of design, we aspire to create a space of mutual reflection that can help us perceive the shifting experience of intended and unintended action and sociocultural change.

Pauline Garvey

Department of Anthropology, Maynooth University, National University of Ireland E-mail: Pauline.A.Garvey@nuim.ie

Pauline Garvey is lecturer in anthropology in Maynooth University, National University of Ireland. Her research interests include material culture and Nordic domesticity, domestic exhibitions in 20th century Sweden, design anthropology and the politics surrounding ethnographic collections in Ireland. Her publications include the co-edited volume (2012) Exhibit Ireland: Ethnographic Collections in Irish Museums (with Seamas O'Siochain and Adam Drazin) and her forthcoming monograph Unpacking Ikea Cultures: Swedish Design for the Purchasing Masses (under contract with Routledge). Pauline is editor of Home Cultures: the Journal of Architecture, Design and Domestic Space (with Victor Buchli and Setha Low).

\section{Adam Drazin}

Department of Anthropology, University College London, UK

Adam Drazin coordinates the MA in Materials.Anthropology. Design in the Anthropology Department at University College London. His two main current research interests are design anthropology, and the Romanian home. He has published in journals and volumes, including Ethnos and Home Cultures. His most recent publication is in the volume he co-edited with Susanne Kuchler (2015), The Social Life of Materials.

If you have any comments to make in relation to this article, please go to the journal website on http://jdh.oxfordjournals.org and access this article. There is a facility on the site for sending e-mail responses to the editorial board and other readers.

\section{Notes}

1 L. Suchman, 'Anthropological Relocations and the Limits of Design', Annual Review of Anthropology, vol. 40, 2011, pp. 1-18, quote from p. 3, emphasis in original.

2 P. Sparke, An Introduction to Design and Culture in the Twentieth Century, Routledge, Abingdon, Oxon., 1986; A. Forty, Objects of Desire: Design and Society since 1750, Thames \& Hudson, London,1986; J. Attfield \& P. Kirkham (eds), A View from the Interior: Feminism, Women and Design, The Women's Press Ltd, London, 1989; J. Attfield, Wild Things: The Material Culture of Everyday Life, Berg, London \& New York, 2000.

3 A. Appadurai, The Social Life of Things: Commodities in Culture Perspective, Cambridge University Press, Cambridge, 1986; D. Miller, Material Culture and Mass Consumption, Blackwell, London,1987. 
4 See A. J. Clarke, 'Theories of Material Agency and Practice: A Guide to Collecting Urban Material Culture', Museum Anthropology, vol. 37, no. 1, 2014, pp. 17-26, for discussion.

5 A. Gell. 'Vogel's Net: Traps as Artworks and Artworks as Traps', in A. Gell, The Art of Anthropology: Essays and Diagrams, E. Hirsh (ed.), Bloomsbury Academic, London, New Delhi, New York \& Sydney, 1999, p. 203; B. Latour, We Have Never Been Modern, Harvard University Press, Cambridge, MA, 1993; B. Latour, Aramis or the Love of Technology, Harvard University Press, Cambridge, MA, 1996. See also W. E. Bijker, T. P. Hughes \& T. Pinch (eds), The Social Construction of Technological Systems: New Directions in the Sociology and History of Technology, MIT Press, Cambridge, MA, 1987.

6 See C. Mulberg, "“Just Don't Ask Me to Define It": Perceptions of Technology in the National Curriculum', Journal of Design History, vol. 6, no. 4, 1993, pp. 301-5; M. Butcher, 'Eel-traps Without Eels', Journal of Design History, vol. 10, no. 4, 1997, pp. 417-29; S. Isenstadt, 'Visions of Plenty: Refrigerators in America Around 1950', Journal of Design History, vol. 11, no. 4, 1998, pp. 311-21.

7 L. Suchman, 'Affiliative Objects', Organisation, vol. 12, no. 3, 2005, pp. 379-99.

8 Suchman, 'Anthropological Relocations and the Limits of Design', op. cit., p. 3. For examples of ethnographic accounts of design see K. M. Murphy, Swedish Design, An Ethnography, Cornell University Press, Ithaca, NY, 2015; J. Krause-Jensen, Flexible Firm: The Design of Culture at Bang and Olufsen, Berghahn Books, New York, 2010; P. Garvey, Unpacking Ikea Cultures: Swedish Design for the Purchasing Masses, Routledge, Abingdon, Oxon., 2016, forthcoming.

9 W. Gunn, T. Otto \& R. C. Smith (eds), Design Anthropology: Theory and Practice, Bloomsbury, London, New York, New Delhi \& Sydney, 2013; J. Blomberg \& H. Karasti, 'Reflections on 25 Years of Ethnography in CSCW', Computer Supported Cooperative Work, nos 4-6, 2013, pp. 373-423; D. Schuler \& A. Namioka, Participatory Design: Principles and Practices, CRC/Lawrence Erlbaum Associates, Mahwah, NJ, 1993; J. Frascara (ed.), Design and the Social Sciences: Making Connections, Taylor \& Francis, London \& New York, 2002.

10 A. J. Clarke, 'Introduction', in Design Anthropology: Object Culture in the 21st Century, A. J. Clarke (ed.), Springer, Vienna \& New York, 2011, pp. 9-13; M. Cefkin (ed.), Ethnography and the Corporate Encounter: Reflections on Research in and of Corporations, Berghahn, Oxford \& New York, 2010. T. Otto \& R. C. Smith, 'Design Anthropology: A Distinct Style of Knowing', in Gunn, Otto \& Smith, op. cit., pp. 1-32; G. Julier, The Culture of Design, 3rd edn, Sage, London, 2013.

11 W Gunn \& J. Donovan 'Design Anthropology: An Introduction', in Design and Anthropology, W. Gunn \& J. Donovan (eds), Ashgate, Surrey, 2012, p. 9.

12 See Gunn \& Donovan, op. cit., p. 1.

13 L. Suchman, L. Blomberg, J. E. Orr \& R. Trigg, 'Reconstructing Technologies as Social Practice', American Behavioral Scientist, vol. 43, no. 3, 1999, pp. 392-408.

14 See L. Suchman, Human-Machine Reconfigurations, Cambridge University Press, Cambridge, 2007; T. Ingold, 'Introduction: The Perception of the User-Producer', in Gunn \& Donovan, op. cit., pp. 19-34.

15 Clarke, op. cit., p. 9.

16 Clarke, op. cit., p. 9.

17 B. Latour, 'A Cautious Prometheus? A Few Steps Towards a Philosophy of Design (with Special Attention to Peter Sloterdijk)', in Networks of Design: Proceedings of the 2008 Annual International Conference of the Design History Society_Falmouth, 3-6 September 2009, F. Hackne, J. Glynne \& V. Minto (eds), BrownWalker Press, Boca Raton, FL, pp. 2-10 (keynote lecture for the Networks of Design meeting of the Design History Society, Falmouth, Cornwall, 3 September 2008).

18 P. Rabinow, G. E. Marcus, J. D. Fabion \& T. Rees, Designs for an Anthropology of the Contemporary, Duke University Press, Durham, NC, 2008. See also A. Appadurai, The Future as Cultural Fact: Essays on the Global Condition, Verso, Brooklyn, NY, \& London, 2013.

19 A. Drazin, 'Design Anthropology: Working on, with and for Digital Technologies', in Digital Anthropology, H. A. Horst \& D. Miller (eds), Berg, London, Oxford \& New York, 2012, pp. 245-65; quote from p. 245.

20 K. Fallan, Design History: Understanding Theory and Method, Bloomsbury Academic, London, New Delhi, New York \& Sydney, 2010; T. Fry, Dilnot \& S. C. Stewart, Design and the Question of History, Bloomsbury Academic, London, New Delhi, New York \& Sydney, 2015.

21 See Y. Kikuchi \& Y. Lee, 'Transnational Modern Design Histories in East Asia: An Introduction', Journal of Design History, vol. 27, no. 4, 2014, pp. 323-34. 